Catalytic reduction of the first three benz(a)acridizinium salts (III-V) over platinum oxide yielded the expected tetrahydroberberine alkaloids. From III, tetrahydroepiberberine ( $\pm \operatorname{sinactin} \theta$, VII) was produced in 50 per cent yield, m.p. $167-168^{\circ}$ (refs. 4 and 5) $169-170^{\circ}, 168^{\circ}$ (found: $\mathrm{C}, 70.55 ; \mathrm{H}, 6 \cdot 16$; $\mathrm{N}, 4 \cdot 22 . \mathrm{C}_{20} \mathrm{H}_{21} \mathrm{NO}_{4}$ requires $\mathrm{C}, 70 \cdot 78 ; \mathrm{H}, 6 \cdot 24$; $\mathrm{N}, 4 \cdot 13$ per cent). The base gives the reported 4,5 colour reaction in a sulphuric-acetic acid mixture. The hydrochloride decomposed at $246^{\circ}$ (refs. 5 and 6 , dec. about $286^{\circ}$; dee. $285-290^{\circ}$; found: $\mathrm{C}, 63.95 ; \mathrm{H}, 5 \cdot 81$. $\mathrm{C}_{20} \mathrm{H}_{21} \mathrm{NO}_{4} \cdot \mathrm{HCl}$ requires $\mathrm{C}, 63 \cdot 91 ; \mathrm{H}, 5.85$ per cent). The reduction of IV yielded tetrahydropseudoepiberberine, m.p. 160 (lit. ${ }^{7}$ m.p. 160-161; found: C, $70 \cdot 85 ; \mathrm{H}, 6 \cdot 37 ; \mathrm{N}, 4 \cdot 20$. $\mathrm{C}_{20} \mathrm{H}_{21} \mathrm{O}_{4} \mathrm{~N}$ requires: $\mathrm{C}, 70 \cdot 78$; $\mathrm{H}, 6.24 ; \mathrm{N}, 4.13$ per cent). The picrate melted at $150^{\circ}$ (d) (ref. 7. m.p. $149-150^{\circ}$ ). The reduction of $\mathrm{V}$ afforded \pm tetrahydropalmatine (m.p. 14. $7^{\circ}$ ) in 53 per cent yield. This material was identical in melting point, mixed melting point and infra-red absorption spectrum with an authentic sample (found: C, 71.08; $\mathrm{H}, 7 \cdot 04 ; \mathrm{N}, 4.24$. $\mathrm{C}_{21} \mathrm{H}_{25} \mathrm{O}_{4} \mathrm{~N}$ requires $\mathrm{C}, 70.99$; $\mathrm{H}, 7.04 ; \mathrm{N}, 3.94$ per cent). The hydrochloride melted at $215-216^{\circ}$ (ref. $8,215^{\circ}$ ).

This investigation was supported by a research grant $(H-2170)$ from the National Heart Institute of the National Institutes of Health, Public Health Service.

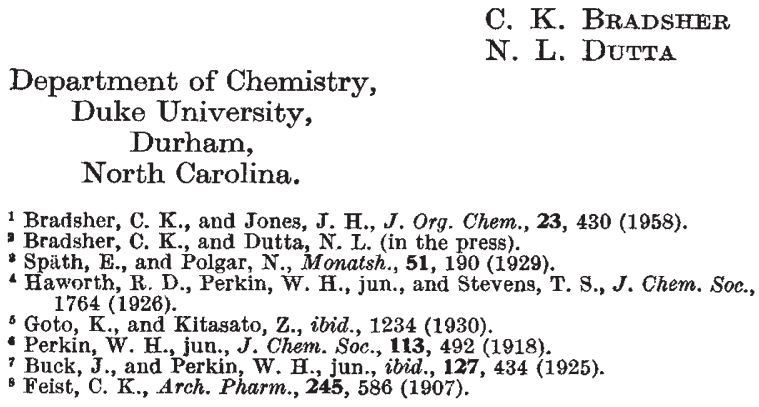

1 Bradsher, C. K., and Jones, J. H., J. Org. Chem., 23, 430 (1958).

Bradsher, C. K., and Dutta, N. L. (in the press).

Späth, E., and Polgar, N., Monatsh., 51, 190 (1929).

Haworth, R. D., Perkin, W. H., jun., and Stevens, T. S., J. Chem. Soc., 1764 (1926).

5 Goto, K., and Kitasato, Z., ibid., 1234 (1930).

- Perkin, W. H., jun., J. Chem. Soc., 113, 492 (1918).

Buck, J., and Perkin, W. H., jun., ibid., 127, 434 (1925).

B Feist, C.'K., Arch. Pharm., 245, 586 (1907).

\section{Formation of Allantoin and Allantoic Acid from Adenine in Leaves of Acer saccharinum $\mathbf{L}$.}

Alrantoin and allantoic acid have been shown to be major constituents of the xylem sap of many species of trees ${ }^{1}$, and have been proposed as important translocatory forms of nitrogen ${ }^{1,2}$. Most workers in ureide metabolism in plants are of the opinion that allantoin and allantoic acid are not formed primarily by purine catabolism, as in the case in animals, but are synthesized from simpler molecules such as urea, glycine, or glyoxylate $2-4$. This communication presents evidence that allantoin and allantoic acid are readily formed from adenine in leaves of silver maple (Acer saccharinum L.).

Adenine-8-14C was fed to two young leaves, through the petioles, in the light. After all the radioactive solution had been absorbed, the leaves were put in 1/10 strength Hoagland's solution. After $24 \mathrm{hr}$. the leaves were washed with water and extracted with 80 per cent ethanol. The ethanol extract was concentrated and chromatographed two-dimensionally in phenol/water and butanol/propionic acid/water solvents. Radioactive compounds were located by radioautography, and activities of the spots were counted directly on the paper with a Geiger-Müller tube.
The majority of the radioactivity from adenine-8-14C appeared in allantoin, allantoic acid, and urea. The radioactivity expressed as percentages of total activity excluding that remaining in adenine, 26 per cent, are given in Table 1.

$\begin{array}{lc}\text { Compound in leaves } & \text { Table 1 } \\ \text { Hypoxanthine } & \text { Per cent radioactivity } \\ \text { Xanthine } & 13 \\ \text { Uric acid } & 14 \\ \text { Allantoin } & 3 \\ \text { Allantoic acid } & 17 \\ \text { Urea } & 27 \\ \text { Ribosides } & 20 \\ \text { Ribotides } & 2 \\ \text { Unkonwn } & 3 \\ \text { Unk } & 1\end{array}$

Some of the urea may, however, have been formed from allantoic acid during the extraction. It is significant that 94 per cent of the total activity on the chromatogram was in compounds previously shown to be involved in purine catabolism in animals. The reaction sequence in maple leaves was therefore indicated to be the same as in animals, namely: adenine $\rightarrow$ hypoxanthine $\rightarrow$ xanthine $\rightarrow$ uric acid $\rightarrow$ allantoin $\rightarrow$ allantoic acid $\rightarrow$ urea plus glyoxylate. All these compounds, save glyoxylate, would be expected to acquire the carbon-14 label from adenine labelled in position 8.

The results indicate that purine catabolism is one process leading to ureide formation in higher plants. The hypothesis that ureides might also be formed directly from simpler molecules has not been investigated by me. An analysis of the xylem sap from a silver maple branch showed that allantoic acid was the major nitrogenous constituent, with glutamine second in abundance. Considerable allantoin, allantoic acid, and urea were present in the foliage. These findings indicate that allantoic acid is indeed an important translocatory and metabolic form of nitrogen in this species. Further investigations of ureide metabolism in several species of forest trees are presently under way.

\section{Robert L. Barnes}

Southeastern Forest Experiment Station Forest Service,

U.S. Department of Agriculture, Duke University,

Durham, North Carolina. Aug. 6.

1 Bollard, E. G., A ustral. J. Biol. Sci., 10, 292 (1957).
2 Mothes, K., and Engelbrecht, L., Flora, 139, 586 (1952).

${ }^{8}$ Brunel, M. A., and Brunel-Capelle, G., C. R. Acad. Sci. Paris, 232, 1130

- Krupka, R. M., and Towers, G. H. N., Canad. J. Bot., 36, 179 (1958).

\section{ANIMAL PHYSIOLOGY \\ Pathophysiological Effects of Circulating Ferritin}

Ferritrs is an iron-containing protein which is stored mainly in the spleen, liver and marrow. The richest source of ferritin is the reticulo-endothelial system of horse spleen; but there is no ferritin in the blood of a healthy horse.

In previous studies ${ }^{1,2}$, a large quantity of ferritin was proved, by the precipitin test and the complement fixation test ${ }^{1}$ to be circulating in the blood of horses suffering from infectious anæmia.

On the other hand, several workers have obtained results which suggest that a small quantity of ferritin (nitrogen $0.0005 \mu \mathrm{gm} . / 0.5 \mathrm{ml}$.) has an effect on the vasodepressor mechanism ${ }^{3,4}$ which inhibits the constrictor response of the muscle capillaries in the 